\title{
Soil Net Organic Nitrogen Mineralization Kinetics in Response to Short- and Long-Term Land-Use Conversion of Woodland to Tea Fields
}

\author{
Dan Chen ${ }^{2}$, Xiaofang Ma ${ }^{3 \#}$, Jieyun Liu ${ }^{1,5 *}$, Cong Wang ${ }^{3 * *}$, Jianqiao Qin ${ }^{4}$
}

${ }^{1}$ Key Laboratory of Water-Saving Irrigation Engineering, Ministry of Agriculture and Rural Affairs, Farmland Irrigation Research Institute, Chinese Academy of Agricultural Science, Xinxiang 453002, China

${ }^{2}$ Key Laboratory of Environment Change and Resources Use in Beibu Gulf Ministry of Education and Guangxi Key Laboratory of Earth Surface Processes and Intelligent Simulation, Nanning Normal University, Nanning 530001, China ${ }^{3}$ College of Forestry, Guangxi University, Nanning 530004, China

${ }^{4}$ School of Environmental and Chemical Engineering, Zhaoqing University, Zhaoqing 526061, China

${ }^{5}$ School of Environment and Surveying Engineering, Suzhou University, Suzhou 234100, China

Received: 21 December 2020

Accepted: 8 March 2021

\begin{abstract}
In recent years, with growing demand for tea consumption, tea cultivation area in China has been increasingly expanded, largely as a result of land-use conversion from woodland into tea field. Up to now, however, soil net nitrogen mineralization kinetics in response to short-and long-term land-use conversion of woodland to tea field remain unclear. Thus, a laboratory aerobic incubation test under constant temperature in combination with a double-pool exponential model were conducted to explore soil organic net nitrogen mineralization dynamics, and quantify soil net nitrogen mineralization kinetics from different planting ages of tea fields $(1,2,3,4,5$, and 30 years old, named T1, T2, T3, T4, T5, and T30 correspondingly) that converted from Masson pine woodland and adjacent woodland (W30, 30 years old). The results showed that land-use conversion exerted great influence on soil physicochemical properties. Though there were no differences in soil total nitrogen (TSN) and total phosphorus (TP) contents between W30 and TN, the TSN and TP were strongly affected by long-tern land-use conversion. The double-pool exponential model fitted soil net nitrogen mineralization data well $\left(\mathrm{R}^{2}\right.$ adj ranged from 0.75 to 0.99 ; RMSE ranged from 0.18 to 0.99 ). The fitted parameter of soil active mineralization organic nitrogen pool $\left(\mathrm{N}_{0}\right)$ and soil active nitrogen mineralization rate constant $\left(k_{1}\right)$ for the woodland soil were $9.09 \pm 2.32 \mathrm{mg} \mathrm{N} \mathrm{kg}^{-1}$ and $0.24 \pm 0.13 \mathrm{~d}^{-1}$, respectively. The $\mathrm{N}_{0}$ for the tea plantation within two years
\end{abstract}

\footnotetext{
\# The first two authors contributed equally to this work.

*e-mail:1115090441@qq.com

**e-mail: wangcuriel@foxmail.com
} 
of the growth stage presented decreasing tendencies, which indicated that soil nitrogen mineralization was stimulated after land-use conversion, and then showed increasing trends with the increasing tea planting ages. Besides, two stepwise regression models developed in this study showed that the nitrogen mineralized kinetic parameters could be well predicted by soil physicochemical properties. In conclusion, soil net nitrogen mineralization is greatly influenced by agricultural land-use conversion and planting ages.

Keywords: land-use conversion, nitrogen mineralization potential, nitrogen mineralized models, parameter estimation, tea plantations with different stand ages

\section{Introduction}

Soil organic nitrogen mineralization, which is generally considered as the transformation of organic nitrogen to inorganic nitrogen, is an important part of soil nitrogen biogeochemical cycle [1]. Mineralization of organic nitrogen reflects the endogenous nitrogen supply capacity of the ecosystem, and represents the important aspect to judge soil fertility [2-4]. Soil ammonium $\left(\mathrm{NH}_{4}^{+}\right)$released by mineralization of organic nitrogen not only can be directly absorbed by crops, but also promotes the production and emission of greenhouse gases as substrate $[1,5]$. Accurate evaluation of soil organic nitrogen mineralization dynamics is crucial for us to understand the soil organic nitrogen mineralization potential and advise the optimized fertilization.

Soil organic nitrogen mineralization is influenced by various factors such as soil total nitrogen (TSN), soil organic carbon (SOC), soil $\mathrm{pH}$, temperature, moisture and so on $[5,6]$. For instance, soil organic nitrogen mineralization was found to increase with the temperature increasing [7]. The soil water availability affects soil organic nitrogen mineralization by changing the number of microorganisms [8]. The changes of land use pattern and management practices may result in the change of soil properties, and thus changes the organic nitrogen mineralization process [2, 9]. For instance, studies have shown that the net mineralization rate of soil organic nitrogen in cultivated soil was significantly higher than that in adjacent forestland and grassland [10]. Screening of key factors that influenced soil organic nitrogen mineralization, and revealing its mechanism have become hotspots in the study of the terrestrial ecosystem nitrogen cycle.

It is essential to evaluate soil organic nitrogen mineralization potential and determine the soil organic nitrogen mineralization kinetics by employing models for guiding scientific fertilization. Currently, models for estimating nitrogen mineralization can be divided into four kinds: hyperbolic model, one-pool exponential model, double-pool exponential model, and special model [11, 12]. A large number of studies have indicated that the double-pool exponential model, which contains active and resistant nitrogen pools considering heterogeneous components of soil organic matter, was usually used frequently and has been found worked better [12].
In recent years, with growing demand for tea consumption, tea cultivation area in China has being increasingly expanded, which has reached nearly 3.05 million ha in 2017, and accounted for approximately $52 \%$ of the world' total acreage [13, 14]. The conversion from woodland into tea field is the most common agricultural practice to achieve faster benefits $[15,16]$. The characteristics of soil organic nitrogen mineralization vary among different land-use types [12]. In contrast to woodland, tea plantations are characteristic with more intensively anthropogenic interference including periodical tillage and fertilization. Research shows that tillage could change soil moisture condition and soil aeration, and thus enhanced soil organic nitrogen mineralization [17]. Tea plant, as an acidophilous and perennial crop, need enough nitrogen fertilizers to satisfy nutrient requirements [18]. The nitrogen fertilizer application rates of tea field in China are usually 450 to $1200 \mathrm{~kg} \mathrm{~N}$ $\mathrm{ha}^{-1} \mathrm{yr}^{-1}[13,19]$ and even more in some cases [13]. Soil organic nitrogen mineralization response to nitrogen addition remains controversial that Luce [20] reported that net nitrogen mineralization may increase with the external nitrogen input, while Kowaljow and Mazzarino hold the opposite opinion [21]. The previous study shows that at the beginning of land use conversion from woodland to tea fields dramatically increased soil nitrogenous gas emissions possibly due to accelerating soil organic nitrogen mineralization [15]. Soil organic nitrogen pool and soil $\mathrm{pH}$ are bound to change with the increasing tea planting age. However, little is known about how planting ages affect the soil organic nitrogen mineralization [22]. In several previous studies, researchers have also measured soil net nitrogen mineralization rates in different agricultural fields and forests [2, 12, 23], but dynamics shifting of nitrogen mineralization kinetics in response to short-and longterm land-use conversion of woodland to tea fields are still lack of understanding.

We hypothesized that the newly converted tea field from woodland in the early stage was greatly disturbed by human activities compared with woodland, which may accelerate the mineralization of soil organic nitrogen; and that soil organic nitrogen mineralization kinetics were greatly affected by different ages of tea plantations. Therefore, we collected topsoil samples from a woodland (W30, aged 30 years), a newly established 
tea plantation (TN), and the adjacent old tea field (T30, aged 30 years). Both tea fields were converted from woodland. Six consecutive years (2013-2018) of soil samples from TN treatments (aged from 0 to 5 years, and named T0, T1, T2, T3, T4, and T5 correspondingly) were collected. Our aims were to: (1) elucidate the response of soil net organic nitrogen mineralization dynamics to land use conversion from woodland to tea field over short and long periods of time, (2) determine the soil organic nitrogen mineralization kinetics and obtain the important soil physicochemical properties that affected the dynamic parameters. This study will reveal soil nitrogen supply potential after conversion of woodland into tea field, and provide scientific references for applying nitrogen fertilizer into tea field.

\section{Material and Methods}

\section{Experimental Site Description and Topsoil Sampling}

Soil sampling site was located in Changsha county $\left(28^{\circ} 32^{\prime} 50^{\prime \prime} \mathrm{N}, 113^{\circ} 19^{\prime} 58^{\prime \prime} \mathrm{E}\right)$, Hunan province, China, where belongs to typically subtropical monsoon climate. The average annual temperature in this region is $17.5^{\circ} \mathrm{C}$, and the mean annual precipitation is $1330 \mathrm{~mm}$ [24]. Woodland and tea field are the typical land-use types in this area.

Topsoil samples were collected from W30, TN, and T30 treatments, respectively. Soils from W30 and T30 treatments have been planted with secondary Masson pine woodland and tea for 30 years, respectively. The TN treatment was established after removal of woodland in 2013. For each treatment, one plot of $\sim 3$ ha was selected and divided into four subplots $\left(600 \mathrm{~m}^{2}\right)$. No fertilizer was applied into woodland. The conventional nitrogen fertilizer application rate in old tea field is $450 \mathrm{~kg} \mathrm{~N} \mathrm{ha} \mathrm{yr}^{-1}$ [25]. The newly converted tea plantation from Masson pine woodland received 0-450 $\mathrm{kg} \mathrm{N} \mathrm{ha-1} \mathrm{yr}^{-1}$ fertilizers depending on the tea ages [15]. The timing and amount of nitrogen fertilization application for the two tea field plots are listed in Supplementary Table S1.

Composite soil samples $(0-20 \mathrm{~cm})$ of each subplot from TN treatments were randomly collected with a stainless auger at 10 points in an ' $\mathrm{S}$ ' shape on typical days in late January every year from 2013 to 2018 before nitrogen fertilizer application, while composite topsoil samples from $\mathrm{W} 30$ and T30 treatments were collected only in late January 2013. The collected soils were naturally air-dried for determining $\mathrm{N}$ mineralization and soil basic physicochemical properties [e.g., SOC, TSN, pH, bulk density (BD), clay content, total P (TP), and total K (TK) content]. SOC was measured by wet oxidation with $\mathrm{H}_{2} \mathrm{SO}_{4}-\mathrm{K}_{2} \mathrm{CrO}_{7}$. TSN was detected using an automated continuous-flow injection analyzer (Seal AA3, Germany) after digested by $\mathrm{H}_{2} \mathrm{SO}_{4}$ and catalysts. Soil $\mathrm{pH}$ was detected with soil and water mixture (1:2.5) by a $\mathrm{pH}$ meter (Metro$\mathrm{pH} 320$, China). BD was measured by cylinders. Clay content $(<0.002 \mathrm{~mm})$ was measured by hydrometer method. Soil TP and TK contents were determined with a spectrophotometer (Lambda 25 UV/VIS spectrophotometer, USA) and atomic absorption spectroscopy (novAA 350, Germany) after fusing with $\mathrm{NaOH}$.

Before measuring nitrogen mineralization, 20-g dry soil was adjusted to $40 \%$ water holding capacity (WHC) by distilled water, weighted into $120-\mathrm{mL}$ glass bottle, and then was dark-pre-incubated in an incubator chamber at $25^{\circ} \mathrm{C}$ for a week for the purpose of activating microorganism. After pre-incubation, soil moisture content was readjusted to $60 \% \mathrm{WHC}$, and the bottles were wrapped in perforated plastic film to exchange gas. Subsequently, soils were incubated for 40 days at $35^{\circ} \mathrm{C}$ and at $95 \%$ relative humidity. In total, twenty-four samples of each composite soil samples were incubated. The samples (three replicates) were extracted with $0.5 \mathrm{~mol} \mathrm{~L}^{-1} \mathrm{~K}_{2} \mathrm{SO}_{4}$ (soil: water $=1: 5$ ) at $0,3,6,9,12,21,28$, and 40 day for measuring the $\mathrm{NH}_{4}^{+}-\mathrm{N}$ and nitrite nitrogen $\left(\mathrm{NO}_{3}^{-}-\mathrm{N}\right)$ concentrations. Soil moisture content is always maintained $60 \% \mathrm{WHC}$ during the whole incubation period by adding distilled water according to the weight changes. Net accumulated soil nitrogen mineralization content was calculated by measuring the inorganic nitrogen $\left(\mathrm{NH}_{4}^{+}-\mathrm{N}\right.$ and $\left.\mathrm{NO}_{3}^{-}-\mathrm{N}\right)$ at each extraction time, then subtracting the inorganic nitrogen at day 0 . An automated flow-injection analyzer (Fiastar 5000, FOSS, Sweden) was used to determine the mineral nitrogen $\left(\mathrm{NH}_{4}^{+}-\mathrm{N}\right.$ and $\left.\mathrm{NO}_{3}{ }^{-} \mathrm{N}\right)$ contents of the soil via extraction with $0.5 \mathrm{~mol} \mathrm{~L}^{-1} \mathrm{~K}_{2} \mathrm{SO}_{4}$ (soil : water $=1: 5)$, respectively.

\section{Calculation and Statistical Analyses}

To determine the soil net organic nitrogen mineralization kinetics, the double-pool exponential model was used to fit the observed mineral $\mathrm{N}$ vs. incubation days:

$$
\mathrm{N}_{\mathrm{t}}=\mathrm{N}_{0} *\left(1-e^{-k_{1} t}\right)+\mathrm{N}_{1} *\left(1-e^{-k_{2} t}\right)(1)
$$

...where $\mathrm{N}_{t}$ presents the net accumulated soil nitrogen mineralization content during time $\left.t(\mathrm{mg} \mathrm{N} \mathrm{kg})^{-1}\right) . \quad \mathrm{N}_{0}$ and $k_{1}$ represent nitrogen mineralization potential, and soil nitrogen mineralization rate constant of the active nitrogen pool, respectively. $\mathrm{N}_{2}$ and $k_{2}$ are the corresponding $\mathrm{N}$ mineralization potential and soil nitrogen mineralization rate constant of the resistant nitrogen pool, respectively [12]. Definite values of $2.5 \times$ $10^{-4}$ and $7.5 \times 10^{-5} \mathrm{~d}^{-1}$ were assigned to the parameter of $k_{2}$ for the woodland and tea plantation, respectively, as they resulted a better performance of the model. Microsoft Excel 2013 software with Solver was used to perform the fitting procedure for soil nitrogen mineralization kinetics. The fraction of soil active nitrogen pool $(f, \%)$ was calculated as follows: 


$$
f=\frac{\mathrm{N}_{0}}{\mathrm{TSN}} * 10^{-1}
$$

All statistical analyses were performed by R statistical software. One-way ANOVA, followed by LSD test at the $5 \%$ level, was used to compare soil physicochemical properties among treatments. Redundancy analyses (RDA) was performed to test the potential correlation between soil nitrogen mineralization kinetics (indicator of soil nitrogen supply potential) and soil basic physicochemical properties. The relationship between the observed and predicted $f$ and $k_{1}$ were examined by the multiple linear regression models. Two diagnostic indicators including the adjusted determination coefficient of the model $\left(\mathrm{R}_{\text {adj }}^{2}\right)$ and the root mean squared error (RMSE) were used to evaluate the performance of the models.

\section{Results}

\section{Soil Physicochemical Properties}

Soil physicochemical properties are summarized in Fig. 1. At the start of the land use conversion experiment, the T0 treatment had the similar soil physicochemical properties with W30 treatment $(p>0.05$, Fig. 1). Land-use conversion from woodland soil to tea plantation significantly affected SOC, C:N ratio, BD, and $\mathrm{pH}$ (Fig. 1). SOC ranged from 6.27 to $12.65 \mathrm{~g}$ $\mathrm{C} \mathrm{kg}^{-1}$ across all treatments. SOC content decreased when converting from woodland into tea plantation, and then increased with the tea age increasing. Soil from all treatments were acidic with $\mathrm{pH}$ 4.01-4.61 (Fig. 1). Soil pH firstly increased and then decreased with the increase of the tea ages. Soil BD was
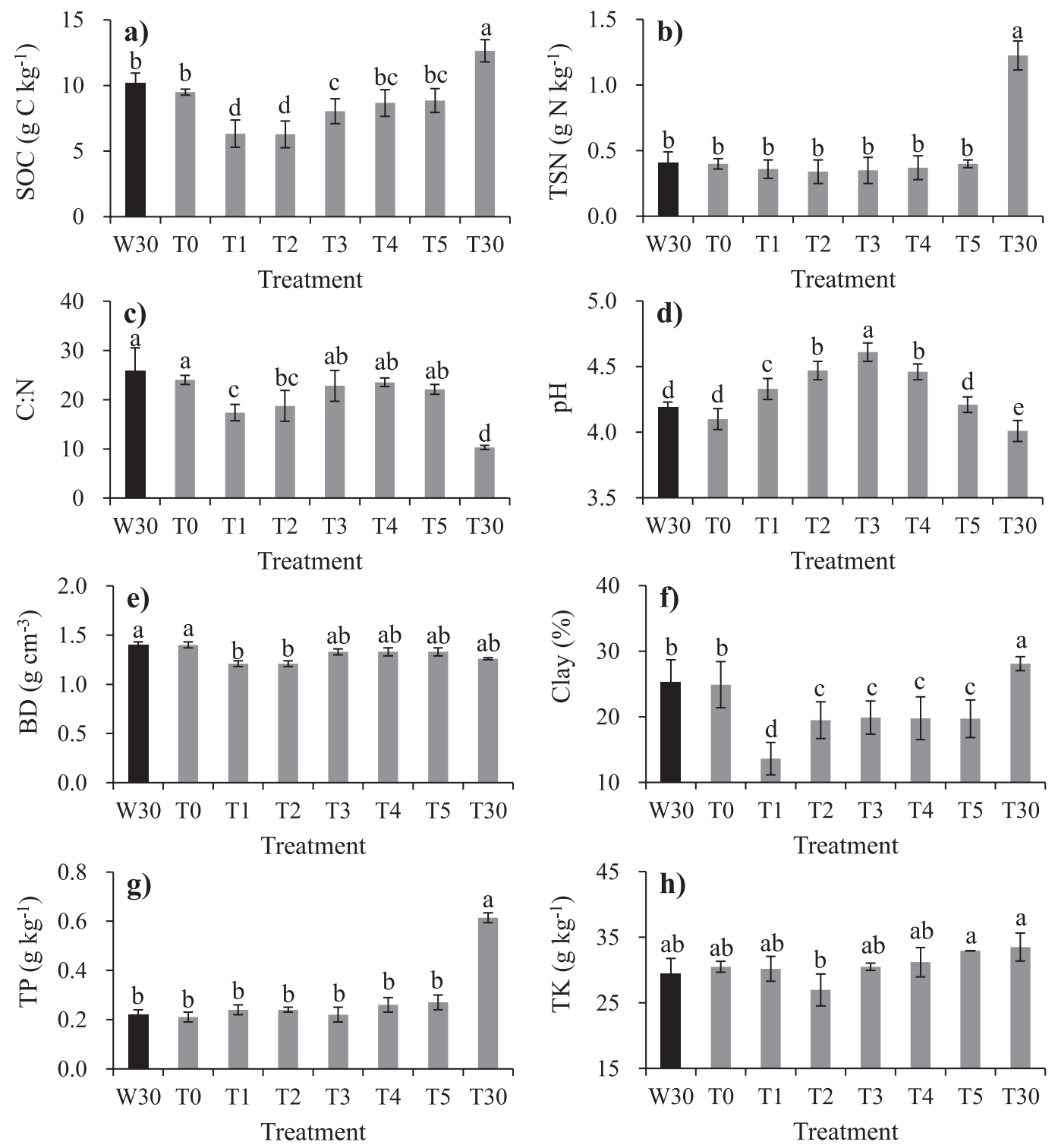

Fig. 1 Comparison of topsoil physicochemical characteristics among the eight treatments. Abbreviation: (a) SOC - total organic carbon, (b) TSN - total nitrogen content, (c) C:N - C:N ratio, (d) pH - soil pH value, (e) BD - bulk density, (f) clay - clay content, (g) TP - total phosphorus, and (h) TK - total potassium. Different letters indicate significant differences at the 0.05 level. 

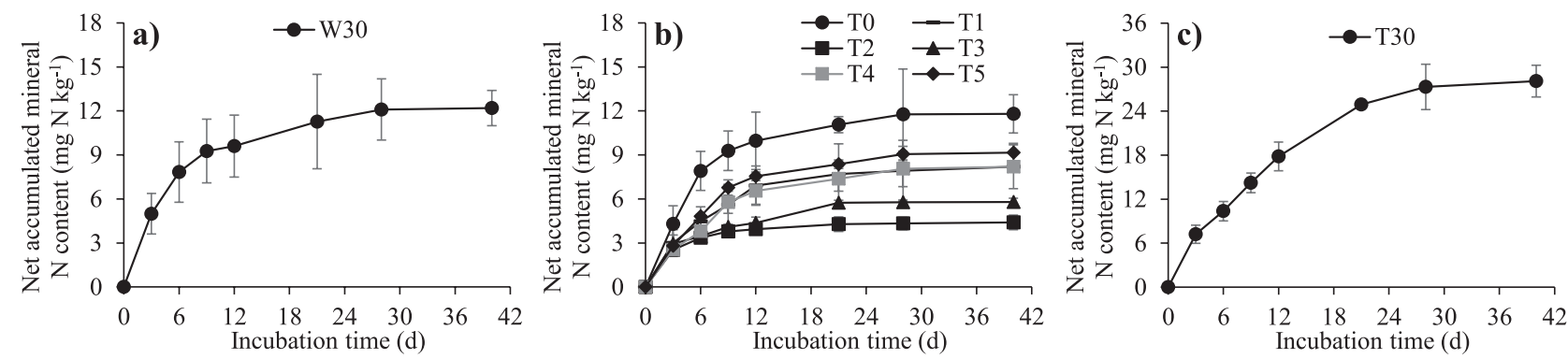

Fig. 2. The dynamics of net accumulated mineral nitrogen concentration in surface $(0-20 \mathrm{~cm})$ soils for a) woodland (W30, aged 30 years), b) newly converted tea field (aged from 0 to 5 years, and named T0, T1, T2, T3, T4, and T5 correspondingly), and c) old tea field (T30, aged 30 years) after 40 days of laboratory incubation at $35^{\circ} \mathrm{C}$.

significantly decreased for the first two years after converting from woodland, and then showed no distinct differences compared with W30 treatment. Compared with W30 and TN treatments, the old tea field soil has higher contents of SOC, TSN, TP and TK, while it has lower C:N ratio and soil $\mathrm{pH}$ (Fig. 1).

\section{Soil Nitrogen Mineralization Kinetics}

The change curves of the net accumulated mineral nitrogen content with the incubation days are showed in Fig. 2. The net accumulated mineral nitrogen content dramatically increased before 12 days of incubation, and then increased smoothly among the eight treatments (Fig. 2). The double-pool exponential model fitted soil nitrogen mineralization data well $\left(\mathrm{R}^{2}\right.$ adj ranged from 0.75 to 0.99 , RMSE ranged from 0.18 to 0.98 , Table 1 ). The fitted parameter of $\mathrm{N}_{0}$ and $k_{1}$ for the W30 treatment were $9.09 \pm 2.32 \mathrm{mg} \mathrm{N} \mathrm{kg}^{-1}$ and $0.24 \pm 0.13 \mathrm{~d}^{-1}$, respectively. The $\mathrm{N}_{0}$ for the TN treatments significantly decreased for the first three years after converting from Masson pine woodland, and then showed an increasing trend with the increasing tea planting age (Table 1).
The active nitrogen mineralization potential among the different ages of tea plantations were in the order of $\mathrm{T} 30>\mathrm{T} 5>\mathrm{T} 4>\mathrm{T} 1>\mathrm{T} 3>\mathrm{T} 2$, and the $\mathrm{N}_{0}$ ranged from 4.94 to $28.07 \mathrm{mg} \mathrm{N} \mathrm{kg}^{-1}$ (Table 1). The $\mathrm{N}_{0}$ of the T30 treatment was significantly higher than that of the W30 treatment, but there was no significant difference on the fraction of soil active nitrogen pool of the two treatments (Table 1). The values of $f$ among the different treatments were in the order of $\mathrm{T} 30 \approx \mathrm{W} 30>\mathrm{T} 5 \approx \mathrm{T} 1 \approx \mathrm{T} 4>\mathrm{T} 3>\mathrm{T} 2$, and the $f$ ranged from $1.06 \%$ to $2.29 \%$ (Table 1). The $\mathrm{T} 2$ treatment had the maximum $k_{1}\left(0.56 \pm 0.03 \mathrm{~d}^{-1}\right)$, while the T30 treatment had the minimum $k_{1}\left(0.08 \pm 0.01 \mathrm{~d}^{-1}\right)$ among the eight treatments (Table 1).

\section{Correlation of Soil N Mineralization Kinetics with Soil Physicochemical Properties}

The correlation analysis showed that the $f$ value was positively correlated with SOC, TSN, BD, and $\mathrm{TK}$, and negatively related to soil $\mathrm{pH}$ (Fig. 3). The $k_{1}$ was negatively related to SOC, TSN, TP, TK and clay content (Fig. 3). The RDA explained approximately $66.4 \%$ of the total variations in the $f$ and $k_{1}$ (Fig. 3).

Table 1. Fitted parameters and statistical indicators for the soil nitrogen mineralization kinetic model for the treatments of woodland (W30, aged 30 years), newly converted tea field (aged from 0 to 5 years, and named T0, T1, T2, T3, T4, and T5 correspondingly), and old tea field (T30, aged 30 years).

\begin{tabular}{|c|c|c|c|c|c|c|}
\hline \multicolumn{2}{|c|}{ Treatment } & $\left(\mathrm{mg} \mathrm{N} \mathrm{kg}^{-1}\right)$ & $(\%)$ & $\left(\mathrm{d}^{-1}\right)$ & $\mathrm{R}_{\text {adj }}^{2}$ & RMSE \\
\hline \multicolumn{2}{|c|}{ W30 } & $9.09 \pm 2.32 \mathrm{~b}$ & $2.24 \pm 0.13 \mathrm{a}$ & $0.24 \pm 0.01 \mathrm{~b}$ & 0.98 & 0.34 \\
\hline \multirow{4}{*}{$\mathrm{T}$} & $\mathrm{T} 0$ & $9.03 \pm 2.22 \mathrm{~b}$ & $2.20 \pm 0.23 \mathrm{a}$ & $0.25 \pm 0.01 \mathrm{~b}$ & 0.98 & 0.32 \\
\cline { 2 - 8 } & $\mathrm{T} 1$ & $7.38 \pm 1.24 \mathrm{c}$ & $2.04 \pm 0.15 \mathrm{~b}$ & $0.16 \pm 0.01 \mathrm{c}$ & 0.99 & 0.18 \\
\cline { 2 - 8 } & $\mathrm{T} 2$ & $3.61 \pm 1.40 \mathrm{~d}$ & $1.06 \pm 0.32 \mathrm{~d}$ & $0.56 \pm 0.03 \mathrm{a}$ & 0.75 & 0.24 \\
\cline { 2 - 8 } & $\mathrm{T} 3$ & $4.94 \pm 0.98 \mathrm{~d}$ & $1.40 \pm 0.24 \mathrm{c}$ & $0.20 \pm 0.02 \mathrm{~b}$ & 0.87 & 0.40 \\
\cline { 2 - 8 } & $\mathrm{T} 4$ & $7.46 \pm 0.87 \mathrm{c}$ & $2.03 \pm 0.16 \mathrm{~b}$ & $0.13 \pm 0.02 \mathrm{c}$ & 0.97 & 0.26 \\
\cline { 2 - 8 } & $\mathrm{T} 5$ & $8.37 \pm 0.14 \mathrm{~b}$ & $2.10 \pm 0.34 \mathrm{~b}$ & $0.15 \pm 0.02 \mathrm{c}$ & 0.99 & 0.25 \\
\hline \multicolumn{2}{|c|}{ T30 } & $28.07 \pm 3.21 \mathrm{a}$ & $2.29 \pm 0.74 \mathrm{a}$ & $0.08 \pm 0.01 \mathrm{~d}$ & 0.98 & 0.98 \\
\hline
\end{tabular}

$\mathrm{N}_{0}, f$, and $k_{1}$ represent the active nitrogen mineralization potential, the fraction of soil active nitrogen pool, and soil active nitrogen mineralization rate constant, respectively. $\mathrm{R}_{\text {adj }}^{2}$ : adjusted determination coefficient, RMSE: root mean squared error.

Different letters indicate significant differences at the 0.05 level. 


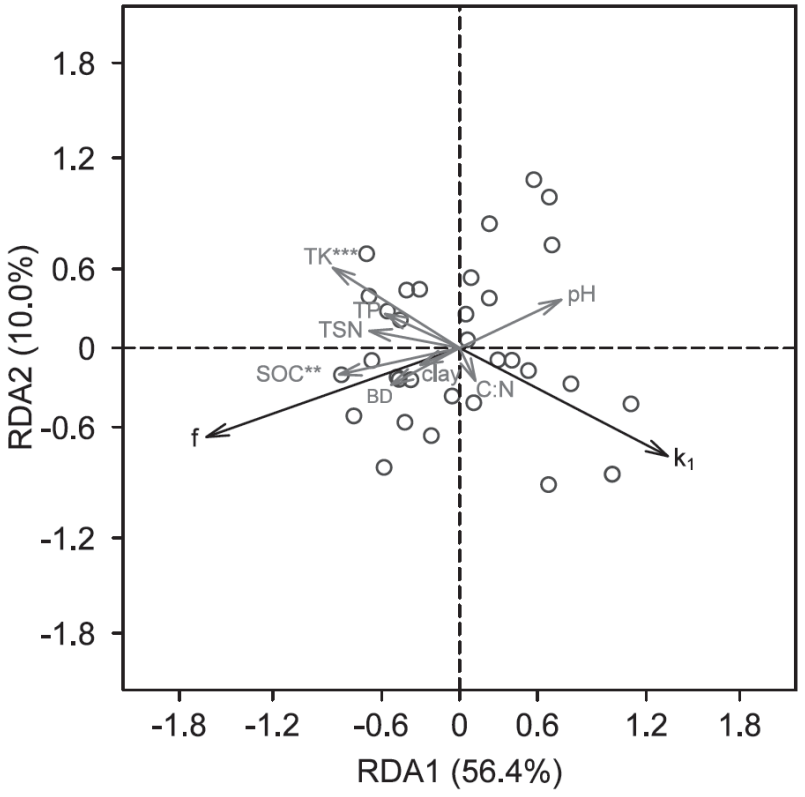

Fig. 3. Redundancy analysis (RDA) tested the associations among the and with soil physicochemical properties. Abbreviation: SOC - total organic carbon, TSN - total nitrogen content, C:N - C:N ratio, $\mathrm{pH}$ - soil $\mathrm{pH}$ value, $\mathrm{BD}$ - bulk density, clay - clay content, $\mathrm{TP}$ - total phosphorus, $\mathrm{TK}$ - total potassium.

SOC and TK were significantly correlated with $f$ and $k_{1}$, accounting for $34.0 \%$ and $17.4 \%$ of the total variations, respectively (Fig. 3). Two stepwise regression models developed in this study showed that the nitrogen mineralized kinetic parameters $\left(f\right.$ and $\left.k_{1}\right)$ could be well described by a combination of soil physicochemical properties as follows (Fig. 4):

$$
\begin{gathered}
f=5.85-1.21 \mathrm{pH}+0.63 \mathrm{SOC}+0.43 \mathrm{TSN} \\
+0.55 \mathrm{TK}+0.25 \mathrm{BD} \quad \mathrm{R}_{\text {adj }}^{2}=0.86, \mathrm{RMSE}=0.17 \\
k_{1}=1.24-0.37 \mathrm{SOC}-0.39 \mathrm{TSN}-0.38 \mathrm{TP} \\
-0.34 \mathrm{TK}-0.57 \text { clay } \quad \mathrm{R}_{\text {adj }}^{2}=0.75, \mathrm{RMSE}=0.09
\end{gathered}
$$

\section{Discussion}

\section{Soil Features}

Soil physicochemical properties, including SOC, TSN, soil $\mathrm{BD}, \mathrm{pH}$, and texture and so on, are strongly affected by land-use change [15, 18, 26, 27]. Woodland soils that compound with rich organic matter, inevitably change soil physicochemical properties when converted into other agricultural land $[15,28]$, which is the same as the case of land-use conversion from woodland soil to tea field in this study. SOC, BD, and clay content in $\mathrm{T} 1$ and $\mathrm{T} 2$ treatments were significantly lower compared with other treatments due to frequent human activities, such as tillage and ditching, which will favor increase in leaching, soil erosion and so
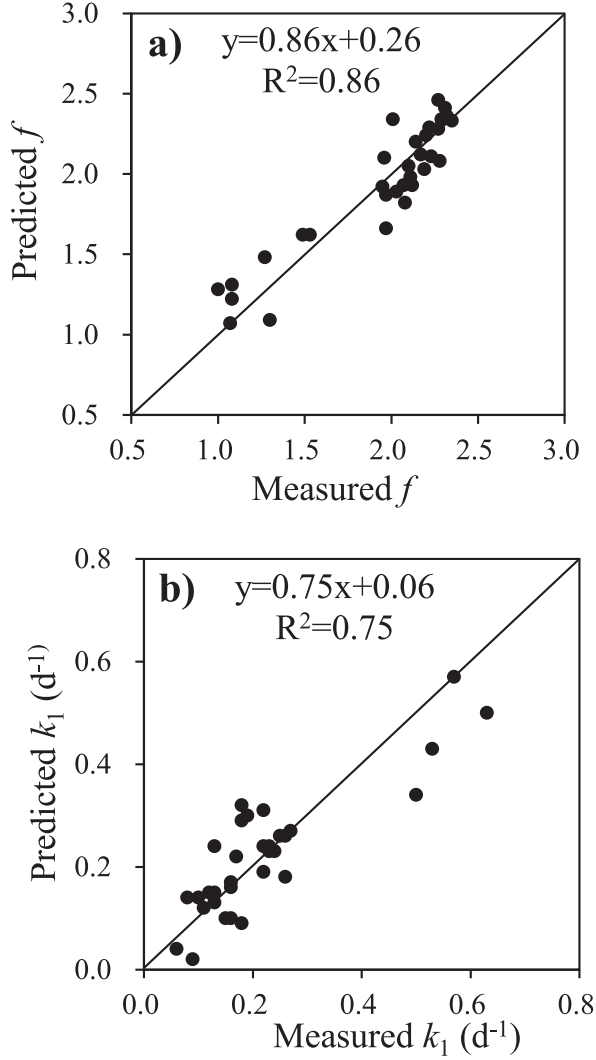

Fig. 4. Relationships between the observed and predicted $f$ a) and $k_{1}$ b) by the multiple linear regression models.

on [28]. Previous study showed that soil particle size fractionation was significantly affected by land leveling [29]. Liu mentioned that soil anti-erosion capacity in the newly converted tea field from forest is low, and topsoil was easily removed by surface flow [30]. Generally, soil with low clay content has a low level of SOC; Tillage for the tea cultivation increased soil organic matter mineralization [15, 31]; which are the main reasons causing the decreasing SOC in T1 and $\mathrm{T} 2$ treatments. The application of $\mathrm{N}$ fertilizer and accumulation of litters help increase SOC after the tea plantation age $\geq 3$ years [32], which was with agreement with our study. Soil $\mathrm{pH}$ firstly increased and then decreased with the increase of the tea ages after converted from woodland. Exchangeable base cations retained in Massion pine tree biomass were transferred into soil when converted into tea field, which attributed to the increase in acidity during the early stages of land use conversion [33]. Subsequently, tea gardens are received large amounts of nitrogen fertilization and root exudates, which lead to decline in soil $\mathrm{pH}[34]$.

\section{Effect of Land Use Conversion on Soil Nitrogen Mineralization}

Soil nitrogen mineralization is greatly affected by agricultural land-use types and managements [2, 12]. The present study showed that the $\mathrm{N}_{0}$ for the newly 
converted tea plantation within two years of the growth stage presented decreasing tendencies, indicating that soil nitrogen mineralization was stimulated after landuse conversion, and thus, resulted in a reduced soil labile mineralization organic nitrogen pool. Tillage for tea cultivation increased soil temperature and soil aeration, and thus enhanced soil organic matter mineralization [35]. In addition, the amount of nitrogen input via nitrogen fertilizer application were relative small for the young tea tree, which may also contribute to the decrease in $\mathrm{N}_{0}$. The soil active organic nitrogen pool began to increase for the newly converted tea plantation with planting ages $\geq 3$ years, but was lower than that of the adjacent 30-year old tea field $\left(\mathrm{N}_{0}=28.07 \mathrm{mg} \mathrm{N} \mathrm{kg}^{-1}\right.$, in this study). This phenomenon could be attributed to the following causes: First, organic nitrogen fertilizer application in tea plantations could increase the soil active nitrogen pool [36]. Second, plant residues and metabolic secretions were accumulated with the increasing years of tea planting ages, which then replenished the pool of soil organic nitrogen [37]. Third, tea plant litter, which contains substances, are difficult to decompose; this delays the mineralization of soil organic nitrogen [38]. Therefore, a relative low soil active nitrogen mineralization rate was observed in the old tea plantation.

Previous studies have shown that soil physicochemical properties strongly affected nitrogen mineralization kinetics $[1,12]$. The positive correlation between the fraction of soil active nitrogen pool with SOC and TSN in the present study is similar with Zou's study [12]. Generally, soil organic nitrogen mineralization is identified as the decomposition of organic substances into inorganic materials by microbes using soil organic matter as substrates and energy [1], which means that the contents of SOC and TSN largely determine the degree of mineralization. A negative correlation between the fraction of soil active nitrogen pool and soil pH was found in this study (Fig. 3), which echoed previous study by [39]. Tea soils are often acidic and Al-rich with the increasing tea ages, which makes the number of microorganisms decrease [40]. Consequently, soil nitrogen mineralization intensity weakens as the $\mathrm{pH}$ descends, and thus increase the soil active nitrogen pool. Soil nitrogen mineralization rate constant was negatively related to SOC, TSN, TP, TK, and clay content (Fig. 3). Research shows that soil organic nitrogen was not easily decomposed by microbes as clay particle content increased [12]. Previous study indicated that the available mineralized organic nitrogen was highest and the mineralization time was the longest (nitrogen mineralization rate constant was the lowest) for upland soil with high SOC, TSN, TP, TK, and clay content due to enhancing microbial immobilization [41, 42]. In addition, soil $\mathrm{C}: \mathrm{N}$ ratio and nitrogen mineralization rate constant in T30 treatment were lower than other treatments. SOC content in T30 treatment may be insufficient to provide energy for maintaining the microbes' metabolism, and therefore the nitrogen mineralization rate constant decreased.

\section{Conclusions}

Soil net nitrogen mineralization is greatly influenced by agricultural land-use conversion and planting ages. The incubation of soil net organic nitrogen mineralization combined with double-pool exponential model indicated that the newly converted tea field within 2-year planting ages enhanced soil organic matter mineralization possibly due to big anthropogenic disturbance. Soil active organic nitrogen pool began to increase for the tea field with planting age $\geq 3$ years. Land-use conversion exerted great influence on soil physicochemical properties, and soil physicochemical properties strongly affected net nitrogen mineralization kinetics.

\section{Acknowledgments}

This research was supported by the Fundamental Research Funds for Chinese Academy of Agricultural Sciences (FIRI2019-01-0202), the Youth Innovation Talents Project of Department of Education of Guangdong Province (2018KQNCX295, 2018KTSCX251), and Zhaoqing Science and Technology Planning Project (2018N001, 2018N007).

\section{Conflicts of Interest}

The authors declare that they have no conflict of interest.

\section{References}

1. ZHU X., BURGER M., DOANE T.A., HORWATH W.R. Ammonia oxidation pathways and nitrifier denitrification are significant sources of $\mathrm{N}_{2} \mathrm{O}$ and $\mathrm{NO}$ under low oxygen availability. PNAS, 110, 6328, 2013.

2. LI D.J., LIU J., CHEN H., ZHENG L., WANG K.L. Soil gross nitrogen transformations in response to land use conversion in a subtropical karst region. Journal of Environmental Management, 212, 1, 2018.

3. OSTERHOLZ W.R., RINOT O., LIEBMAN M., CASTELLANO M.J. Can mineralization of soil organic nitrogen meet maize nitrogen demand? Plant Soil, 415, 73e84, 2017.

4. RAHMAN M.M., BÁRCENA T.G., VESTERDAL L. Tree species and time since afforestation drive soil $\mathrm{C}$ and $\mathrm{N}$ mineralization on former cropland. Geoderma, 305, 153, 2017.

5. KADER M.A., SLEUTEL S., BEGUM S.A., MOSLEHUDDIN A.Z.M. Nitrogen mineralization in subtropical paddy soils in relation to soil mineralogy, management, $\mathrm{pH}$, carbon, nitrogen and iron contents. European Journal of Soil Science, 64, 47, 2013. 
6. XIAO K.C., XU J.M., TANG C.X., ZHANG J.B., BROOKES P. Differences in carbon and nitrogen mineralization in soils of differing initial $\mathrm{pH}$ induced by electrokinesis and receiving crop residue amendment. Soil Biology \& Biochemistry, 67, 70, 2013.

7. GUNTIÃS M.E., LEIRÓS M.C., TRASAR-CEPEDA C., GIL-STOTRES F. Effects of moisture and temperature on net soil nitrogen mineralization: A laboratory study. European Journal of Soil Biology, 48, 73, 2012.

8. HU R., WANG X.P., PAN Y.X., ZHANG Y.F., HAO $Z$. The response mechanisms of soil $\mathrm{N}$ mineralization under biological soil crusts to temperature and moisture in temperate desert regions. European Journal of Soil Biology, 62, 66, 2014.

9. KADER M., SLEUTEL S., BEGUM S.A., MOSLEHUDDIN A.Z.M., NEVE S.D. Nitrogen mineralization in subtropical paddy soils in relation to soil mineralogy, management, $\mathrm{pH}$, carbon, nitrogen and iron contents. European Journal of Soil Science, 64, 47, 2013.

10. YANG L., ZHANG F., GAO Q., MAO R., LIU X. Impact of land-use types on soil nitrogen net mineralization in the sandstorm and water source area of Beijing, China. Catena, 82, 15, 2010.

11. KUMAR M., KUNDU D.K., GHORAI A.K., MITRA S. Carbon and nitrogen mineralization kinetics as influenced by diversified cropping systems and residue incorporation in Inceptisols of eastern Indo-Gangetic Plain. Soil and Tillage Research, 178, 108, 2018.

12. ZOU G.H., ZHAO F.L., SHAN Y., LI Y. Pedo-transfer function to estimate kinetic parameters for anaerobic soil nitrogen mineralization. Open Journal of Soil Science, 8, 75, 2018.

13. HAN W.Y., XU J.M., WEI K., SHI Y.Z., MA L.F. Estimation of $\mathrm{N}_{2} \mathrm{O}$ emission from tea garden soils, their adjacent vegetable garden and forest soils in eastern China. Environmental Earth Sciences, 70, 2495, 2013.

14. CHEN Z.M. Innovation and development of China tea industry in new era. Journal of Agriculture, 8, 80, 2018. [In Chinese].

15. CHEN D., LI Y., WANG C., LIU X.L., WANG Y., SHEN J.L., QIN J.Q., WU J.S. Dynamic and underlying mechanisms of $\mathrm{N}_{2} \mathrm{O}$ and $\mathrm{NO}$ emissions in response to a transient land-use conversion of Masson pine forest to tea field. Science of the Total Environment, 693, 133549, 2019.

16. ZHU T., ZHANG J., MENG T., ZHANG Y., YANG J., MÜLLER C., CAI Z. Tea plantation destroys soil retention of NO3- and increases $\mathrm{N}_{2} \mathrm{O}$ emissions in subtropical China, Soil Biology \& Biochemistry, 73, 106, 2014.

17. WELLER S., JANZ B., JÖRG L., KRAUS D., WASSMANN R., BUTTERBACH-BAHL K., KIESE R. Greenhouse gas emissions and global warming potential of traditional and diversified tropical rice rotation systems. Global Change Biology, 22, 4323, 2016.

18. WU Y.Z., LI Y., FU X.Q., SHEN J.L., CHEN D., WANG Y., LIU X.L., XIAO R.L., WEI W.X., WU J.S. Effect of controlled-release fertilizer on $\mathrm{N}_{2} \mathrm{O}$ emissions and tea yield from a tea field in subtropical central China. Environmental Science and Pollution Research, 26, 1, 2018.

19. LI Y., ZHENG X.H., FU X.Q., WU Y.Z. Is green tea still 'green'? Geography and Environment, 3, e00021, 2016.

20. LUCE M.T., WHALEN J.K., ZIADI N., ZEBARTH B.J. Net nitrogen mineralization enhanced with the addition of nitrogen-rich particulate organic matter. Geoderma, 262, 112, 2016.

21. KOWALJOW E., MAZZARINO M.J. Soil restoration in semiarid Patagonia: chemical and biological response to different compost quality. Soil Biology \& Biochemistry, 39, 1580, 2007.

22. RAHMAN M.M., BÁRCENA T.G., VESTERDAL L. Tree species and time since afforestation drive soil $\mathrm{C}$ and $\mathrm{N}$ mineralization on former cropland. Geoderma, 305, 153, 2017.

23. CHENG Y., CHANG S.X., CAI Z.C., MÜLLER C., ZHANG J.B. Nitrogen deposition affects both net and gross soil nitrogen transformations in forest ecosystems: A review. Environmental Pollution, 244, 608, 2018.

24. LI Y., FU X.Q., LIU X.L., SHEN J.L., LUO Q., XIAO R.L., LI Y., TONG C.L., WU J.S. Spatial variability and distribution of $\mathrm{N}_{2} \mathrm{O}$ emissions from a tea field during the dry season in subtropical central China. Geoderma, 193, $1,2013$.

25. CHEN D., LI Y., WANG C., FU X.Q., LIU X.L., SHEN J.L., WANG Y., XIAO R.L., LIU D.L., WU J.S. Measurement and modeling of nitrous and nitric oxide emissions from a tea field in subtropical central China. Nutrient Cycling in Agroecosystems, 107, 157, 2017.

26. WU L., TANG S.R., HE D.D., WU X., SHAABAN M., WANG M.L., ZHAO J.S., KHAN I., ZHENG X.H., HU R.G., HORWATH R. Conversion from rice to vegetable production increases $\mathrm{N}_{2} \mathrm{O}$ emission via increased soil organic matter mineralization. Science of the Total Environment, 583, 190, 2017.

27. MEURER K., FRANKO U., STANGE C.F., ROSA J., MADARI B., JUNKUNST H.F. Direct nitrous oxide $\left(\mathrm{N}_{2} \mathrm{O}\right)$ fluxes from soils under different land use in Brazil-a critical review. Environmental Research Letters, 11, 1748, 2016.

28. LI H.M., MA Y.X., LIU W.J., LIU W.J. Soil changes induced by rubber and tea plantation establishment: comparison with tropical rain forest soil in Xishuangbanna, SW China. Environmental Management, 50, 837, 2012.

29. BRYE K.R., SLATON N.A., SAVIN M.C., NORMAN R.J., MILLER D.M. Short-term effects of land leveling on soil physical properties and microbial biomass. Soil Science Society of America Journal, 67, 1405, 2003.

30. LIU J., WANG Y., LI Y., LIU X.L., JIANG Y.X., FU YX., JIN W.B., WU S.S. Ecosystem N:P stoichiometric ratios determine the catchment surface water $\mathrm{N}: \mathrm{P}$ ratio through subsurface hydrological processes. Catena, 194, 104740, 2020.

31. WANG H., GUAN D., ZHANG R., CHEN Y., HU Y., XIAO L. Soil aggregates and organic carbon affected by the land use change from rice paddy to vegetable field. Ecological Engineering, 70, 206, 2014.

32. MAHRER A., HEMMATI V., HASHEMI S.A. Effect of conversion forest to the tea gardens on the organic carbon nitrogen and phosphorus in the soil (case study: north of Iran). Indian Journal of Fundamental Applied Life Sciences, 4, 432, 2014.

33. YAMASHITA N., OHTA S., HARDJONO A. Soil changes induced by Acacia mangium plantation establishment: comparison with secondary forest and Imperata cylindrical grassland soils in South Sumatra, Indonesia. Forest Ecology and Management, 254, 362, 2008.

34. HUANG Y., LI Y.Y., YAO H.Y. Nitrate enhances $\mathrm{N}_{2} \mathrm{O}$ emission more than ammonium in a highly acidic soil. Journal of Soil Sediment, 14, 146, 2014.

35. YAN P., SHEN C., FAN L.C., LI X., ZHANG L.P., ZHANG L., HAN W.Y. Tea planting affects soil acidification and nitrogen and phosphorus distribution in soil. Agriculture, Ecosystems and Environment, 254, 20, 2018. 
36. YAN E.R., WANG X.H., HUANG J.J., LI G.Y., ZHOU W. Decline of soil nitrogen mineralization and nitrification during forest conversion of evergreen broad-leaved forest to plantations in the subtropical area of Eastern China. Biogeochemistry, 89, 239, 2008.

37. ZHU R.H., ZHENG Z.C., LI T.X., ZHANG X.Z., HE S.Q., WANG Y.D., LIU T., LI W. Dynamics of soil organic carbon mineralization in tea plantations converted from farmland at Western Sichuan, China. Plos One, 12, e0185271, 2017.

38. FAN D., FAN K., YU C., LU Y., WANG X. Tea polyphenols dominate the short-term tea (Camellia sinensis) leaf litter decomposition. Journal of Zhejiang University-SCIENCE B (Biomedicine \& Biotechnology), 18, 99, 2017.

39. ZHENG J., ZHANG J.Z., ZHAI L.M., LIU H.B. Nitrogen mineralization and its influence factors in the farmland soils of Erhai Lake Basin. Chinese Environmental Science, 30, 35, 2010.

40. HAN W.Y., XU J.M., WEI K., SHI Y.Z., MA L.F. Estimation of $\mathrm{N}_{2} \mathrm{O}$ emission from tea garden soils, their adjacent vegetable garden and forest soils in eastern China. Environmental Earth Sciences, 70, 2495, 2013.

41. ZHANG YL., CHEN W.F., YU N., FU SF., ZHANG YL., ZOU H.T. Long-term effects of different land use patterns on mineralizing characteristic of soil organic nitrogen. Chinese Journal of Soil Science, 44, 52, 2013.

42. XIONG J.P., DING S.J., WANG X.C., MA X.M., WU Y.X., DU P., YU X.H. Biological factors influencing nitrogen transformation in wheat fields of line concreted black soils and their response to different nitrogen supplications. Chinese Journal of Eco-Agriculture, 24, 563, 2016.

\section{Supplementary Information}

Table S1. Cultivation and fertilization management practices for the newly converted tea field $\left(\mathrm{T} \_\mathrm{N}\right)$ during the studying period.

\begin{tabular}{|c|c|c|c|}
\hline Treatment & Fertilizer type & Date & Rates $\left(\mathrm{kg} \mathrm{N}^{-1}\right)$ \\
\hline $\mathrm{TN}$ & Urea & 26 Feb 2013 & 150 \\
\hline & Oilseed residues* & 18 Dec 2013 & 100 \\
\hline TO & Oilseed residues & 20 Apr 2013 & 150 \\
\hline & Rice straw & 04 Aug 2013 & 150 \\
\hline & Urea & 26 Dec 2015 & 300 \\
\hline & Oilseed residues & 03 Mar 2016 & 150 \\
\hline & Urea & 16 Dec 2016 & 300 \\
\hline
\end{tabular}

Oilseed residues contained $5.9 \%$ of $\mathrm{N}$ and had a C: $\mathrm{N}$ ratio of 5.1 
